\title{
Event-specific multiplex PCR method for four genetically modified cotton varieties, and its application
}

\author{
Soon-Jae Eum, II Ryong Kim, Hye Song Lim, Jung Ro Lee and Wonkyun Choi* (D)
}

\begin{abstract}
Multiplex polymerase chain reaction (PCR) methods have been developed and validated for screening, tracing, and regulating genetically modified (GM) crops in quarantine and environmental monitoring. In this study, we aimed to develop a method to simultaneously detect four GM cotton varieties in order to establish a screening system for cotton volunteers. Based on the sequence of DNA in the junction between introduced gene and flanking genomic DNA of four GM cotton events, herbicide-tolerant MON88701 and DAS-81910-7 and insect-resistant COT102 and T304-40, event-specific primers were designed and a multiplex detection method was developed. The simplex PCR results supported the multiplex PCR results; the amplification efficiency of the novel multiplex PCR method was increased compared with that of the Joint Research Centre (JRC) method. Based on the accuracy and efficiency, the method can be applied to detect and identify randomly mixed reference materials and suspected cotton volunteers. To apply this multiplex PCR method to living modified (LM) environmental monitoring samples, we performed additional PCR analysis to identify whether the volunteers were the four LM cotton varieties. As a result, 66 cotton volunteers were identified with stack event, comprising one or two of the four LM cotton events, and all stacks have been approved in South Korea for food, feed, and processing. These results indicated that our novel multiplex method is suitable for LMO identification.
\end{abstract}

Keywords: Cotton, Living modified organism, LMO detection, Multiplex PCR

\section{Introduction}

Innovations in modern biotechnology have led to the development of genetically modified (GM) crops with herbicide tolerance (HT), insect resistance (IR), and quality and production improvements. In 2017, over 67 countries adopted GM crops and 25 countries cultivated GM crops on 189.8 million hectares-an increase of $3 \%$ from 2016 - for food, feed, and processing [1]. These GM crops have been expanded beyond maize, soybean, canola, and cotton, which are commercial crops, to include alfalfa, sugar beet, papaya, potato, and apple.

Cotton (Gossypium hirsutum L.) is a primary natural fiber and major oilseed crop with a global planting area of approximately 30.2 million hectares. In 2017, GM cotton

*Correspondence: wonkyun@nie.re.kr

Division of Ecological Safety, National Institute of Ecology, Seocheon 33657, Republic of Korea varieties accounted for 24.1 million hectares (18 million hectares with IR varieties, 0.82 million hectares with HT varieties, and 5.2 million hectares with IR/HT varieties) of cultivation area, and they were planted in 14 countries [1]. COT102 is an insect-resistant variety, developed by Syngenta (Basel, Switzerland), in which the Vip3A(a) protein is expressed to confer resistance to feeding damage by lepidopteran pests. MON88701 has two bacterial genes, namely $b a r$ and $d m o$, to provide resistance against the herbicides glufosinate and dicamba; it was developed by Monsanto (St. Louis, MO, USA). T304-40 was developed by BASF (Ludwigshafen, Germany). It has the Cry1Ab and bar genes, conferring IR/HT. DAS-81910-7, which was developed by Dow AgroSciences LLC (Indianapolis, IN, USA), has the aad-12 and pat genes, conferring resistance against 2,4-dichlorophenoxyacetic acid (2,4-D) and glufosinate. The IR/HT genes introduced in 
these crops are from bacteria such as Bacillus thuringiensis (vip3a and crylab), Streptomyces hygroscopicus (bar), Stenotrophomonas maltophilia (dmo), Delftia acidovorans (aad-12), and Streptomyces viridochromogenes (pat).

Although GM plants have been cultivated for food and feed in several countries, numerous issues still persist, such as human health effects, biosafety, environmental risk, and ethical concerns [2]. Therefore, high-accuracy and high-throughput standardized detection methods of GM crops are in demand to regulate the use of GM crops to their purpose and to control unintentional environmental release. Nucleic acid- and protein-based methods are commonly used for detection of genetically modified organisms (GMOs). Among the nucleic acid-based methods, PCR detection methods including simplex and multiplex PCRs are widely applied owing to their high sensitivity and accuracy [3]. They have been applied in GM crop detection for screening and quantifying GM crop-derived DNA. There has been a demand for multiplex methods for the simultaneous detection of GMOs due to the increase in single and stack events. These simultaneous detection methods are especially useful for detecting GMOs in mixed samples or stack events that contain multiple exogenous genes. The detection methods for GM cotton have been developed using frequently present genetic elements such as p35S, T-nos, T-35 s, cp4 epsps, pat, bar, and cry1Ab/Ac [4, 5]. The development of new techniques such as real time PCR has led to advances in GM cotton detection [3, 6, 7]. However, the application of these real-time PCR detection methods is limited as they require expensive laboratory equipment [8]; hence, there is a need to develop conventional multiplex PCR detection methods for GMO identification.

In this study, we aimed to develop a method to simultaneously detect four GM cotton varieties in order to establish a screening system for cotton volunteers. To validate the developed multiplex PCR method, we applied the limit of detection, randomly mixed reference materials (RMs), and living modified organism (LMO) monitoring sample analysis. This method can help efficiently monitor four GM cotton events in a single reaction and will benefit GMO testing in food or processed products.

\section{Materials and methods}

\section{Reference materials and plant samples}

Reference materials of GM cotton (COT102, T304-40, MON88701, and DAS-81910-7) were obtained from the Institute for Reference Materials and Measurements (IRMM, Geel, Belgium) and the Oil Chemists' Society (AOCS, Urbana, IL, USA). Cotton volunteers were collected from the LMO environmental monitoring project of the National Institute of Ecology (Korea) in 2018, dried with $\mathrm{SiO}_{2}$ (DUKSAN, Ansan, Korea), and stored at $-80^{\circ} \mathrm{C}$ until DNA extraction.

\section{DNA extraction}

Genomic DNA was extracted from cotton RMs and leaf tissue of cotton volunteers using the DNeasy Plant Mini Kit (Qaigen, Hilden, Germany), following the manufacturer's recommendations. The amount of total genomic DNA was measured using the spectrophotometer ND-2000 (Thermo Fisher Scientific, Wilmington, DE, USA), and then the final concentration was adjusted to $50 \mathrm{ng} / \mu \mathrm{L}$ for analysis. The quantity of the DNA was confirmed by $1.0 \%$ agarose gel electrophoresis (data not shown). The extracted DNA samples were stored at $-20^{\circ} \mathrm{C}$ until further use.

\section{PCR analysis}

The information about LM cotton events was obtained from the Joint Research Centre of the European Commission (JRC-EC) and the Center for Environmental Risk Assessment (CERA). Event-specific primers were designed and applied to establish the multiplex PCR method; alcohol dehydrogenase $\mathrm{C}(A D H 1)$ was used as the PCR control. The primers were purchased from Macrogen Inc. (Seoul, Korea) and were diluted in nucleasefree water (Qiagen, Germany). For simplex and multiplex PCRs, we used the $2 \times$ EF-Taq PCR Pre-Mix (Solgent, Daejeon, Korea) in a reaction mixture of $30 \mu \mathrm{L}$ total volume, containing $50 \mathrm{ng}$ of genomic DNA, from RMs or volunteer samples, and event-specific primers. The reaction mixture was amplified using the Proplex PCR system (Applied Biosystems, Waltham, MA, USA) under the following conditions: initial denaturation at $95{ }^{\circ} \mathrm{C}$ for $5 \mathrm{~min}$; 35 cycles of denaturation at $95^{\circ} \mathrm{C}$ for $0.5 \mathrm{~min}$, annealing at $58{ }^{\circ} \mathrm{C}$ for $0.5 \mathrm{~min}$, and extension at $72{ }^{\circ} \mathrm{C}$ for $0.5 \mathrm{~min}$; and one cycle of final extension at $72{ }^{\circ} \mathrm{C}$ for $5 \mathrm{~min}$. The PCR products $(10 \mu \mathrm{L})$ were resolved on $2.5 \%(\mathrm{w} / \mathrm{v})$ agarose gel by electrophoresis and gel images were obtained using Chemi-Doc ${ }^{\mathrm{TM}} \mathrm{XRS}^{+}$(Bio-Rad, Hercules, CA, USA).

\section{Sensitivity and practical application of the developed multiplex PCR method}

To confirm the sensitivity and efficiency of the newly developed multiplex PCR method, we performed multiplex PCR with a randomly mixed RM DNA template, four serially diluted RM DNA mixtures, and 81 LM cotton volunteer samples; we also employed the limit of detection (LOD) assay. Mixed RM DNA templates were serially diluted with non-LM cotton genomic DNA for the LOD assay $(50,25,12.5,6.25,3.12,1.56,0.78,0.39$, 0.19 , and $0 \mathrm{ng} / \mu \mathrm{L})$. Randomly mixed RM DNA samples were used to test whether the developed multiplex PCR method could detect two or three randomly mixed 
DNA samples and one or four randomly mixed RMs. To confirm the practical application of the multiplex PCR for LMO monitoring, volunteer cotton leaf samples from LMO environmental monitoring were analyzed.

\section{Results}

Establishment of a multiplex PCR method

To develop a multiplex PCR method for cotton, we collected basic information about the four LM cotton events (Fig. 1) and designed event-specific simplex PCR primers (Table 1). These event-specific primers for the flanking

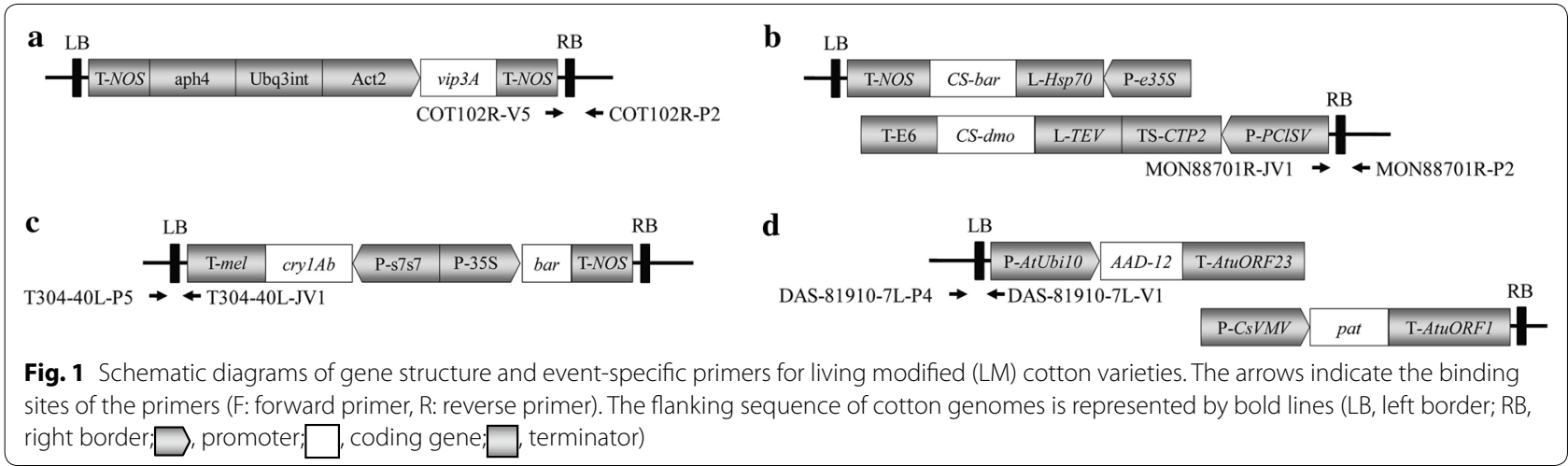

Table 1 List of primers used for cotton multiplex PCR method

\begin{tabular}{|c|c|c|c|c|}
\hline Event name & Primer name & Primer sequence $\left(5^{\prime}-3^{\prime}\right)$ & GC (\%) & Size (bp) \\
\hline \multirow[t]{7}{*}{ COT102 } & COT102R-P2 & CGGAGTCTATTACAGTAACAGTACAGT & 41 & - \\
\hline & COT102R-V0 & TGTGACACCGATCCACCTAA & 50 & 665 \\
\hline & COT102R-V1 & ACCAAGTTCGAGAAGGACAAC & 48 & 641 \\
\hline & COT102R-V2 & ATCAAGTAGGAGCTCTAGATCC & 45 & 551 \\
\hline & COT102R-V3 & ATATAGCGCGCAAACTAGGATA & 41 & 322 \\
\hline & COT102R-V4 & CCAATTGATTTAAATGGCCGCTG & 43 & 231 \\
\hline & COT102R-V5 & GCTCATGATCAGATTGTCGTT & 43 & 108 \\
\hline \multirow[t]{7}{*}{ MON88701 } & MON88701R-JV1 & CATACTCATTGCTGATCCATGTAGA & 40 & - \\
\hline & MON88701R-JP1 & AGTGTTAAACAAGTTATGTTCTAGAGC & 33 & 84 \\
\hline & MON88701R-P1 & GTCAATGGCATAAACTTATATTTAGTG & 30 & 107 \\
\hline & MON88701R-P2 & GTCTCGTGGTTTAAATCTTCTAAATT & 31 & 205 \\
\hline & MON88701R-P3 & GATCATGTCATTATCAATTAAGTGTTAC & 29 & 349 \\
\hline & MON88701R-P4 & GACTCATCTAAATTAGACACTG & 36 & 440 \\
\hline & MON88701R-P5 & CCAATTTTGGTTACCCAAGT & 40 & 499 \\
\hline \multirow[t]{7}{*}{ Т304-40 } & T304-40L-JV1 & CCTAGATCTTGGGATAACTTGAAAAGA & 37 & - \\
\hline & T304-40L-JP1 & AGCGCGCAAACTAGGATAAATT & 41 & 78 \\
\hline & T304-40L-P1 & ATTAGAGTCCCGCAATTATAC & 38 & 127 \\
\hline & T304-40L-P2 & ATGACGTTATTTATGAGATGGG & 36 & 157 \\
\hline & T304-40L-P3 & GTTGAATTACGTTAAGCATGTAAT & 29 & 197 \\
\hline & T304-40L-P4 & TTAAGATTGAATCCTGTTGCC & 38 & 247 \\
\hline & T304-40L-P5 & GATCGTTCAAACATTTGGCA & 40 & 277 \\
\hline \multirow[t]{5}{*}{ DAS-81910-7 } & DAS-81910-7L-V1 & CTTTTGGTGTGATGATGCTG & 45 & - \\
\hline & DAS-81910-7L-P1 & GCATTCGGCAACTTACTT & 44 & 114 \\
\hline & DAS-81910-7L-P2 & GCTTGAATATGAGATTTGTAATGTGA & 31 & 218 \\
\hline & DAS-81910-7L-P3 & GATGGATGTTAAGCTAATTGGG & 41 & 299 \\
\hline & DAS-81910-7L-P4 & TGATGTTGTTTTTTGATGCTTTAGG & 33 & 371 \\
\hline \multirow[t]{2}{*}{ AdhC } & AdhC F & TCCAGAGGCTCCACTTGAT & 53 & 178 \\
\hline & AdhC R & CCCACCCTTTTTTGGTTTAGC & 48 & \\
\hline
\end{tabular}



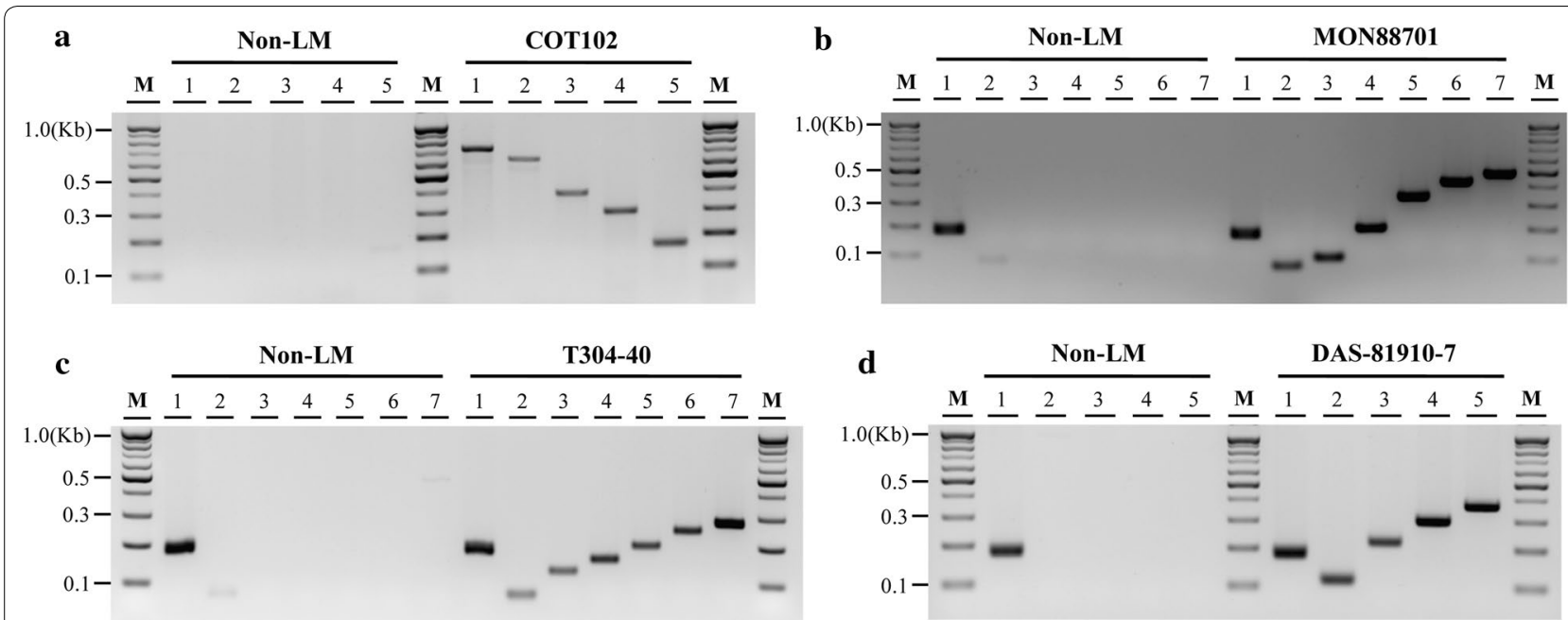

Fig. 2 Confirmation of the simplex PCR primer set for the four living modified (LM) cotton varieties. a-d PCR product of the four LM cotton events: a COT102; b MON88701; c T304-40; d DAS-81419-7. The PCR products were electrophoresed on a 2.5\% agarose gel. Lane 1, AdhC (endogenous gene) primer; lane 2, JRC method primer; lanes 3-7, event-specific primer sets. M represents 100 bp marker

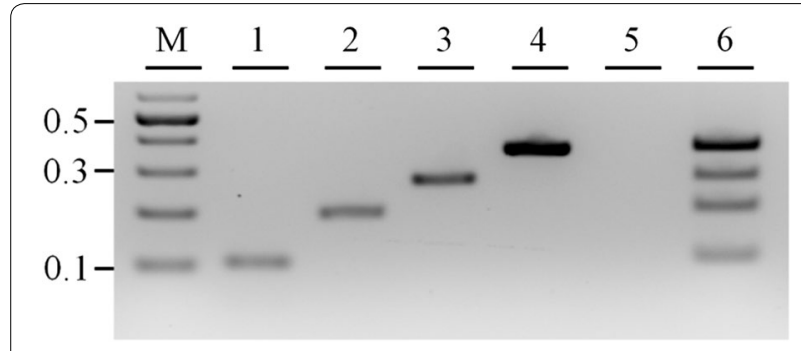

Fig. 3 Establishment of multiplex PCR. The multiplex PCR with each genomic DNA template [lane 1, COT102; lane 2, MON88701; lane 3, T304-40; lane 4, DAS81419-7; lane 5, non-LM cotton; lane 6, mixed four living modified organism reference materials (LMO RMs)] was performed. M represents $100 \mathrm{bp}$ marker

cotton genome sequence and the introduced LM gene were tested and the primers with high efficiency were selected. All simplex PCR primers showed event-specific amplification without any non-specific bands. These simplex PCR results indicated that the newly developed simplex PCR primers (Fig. 2b-d, lanes 3-7) showed increased PCR band intensity than the JRC method primer set (Fig. 2b-d, lane 2).

Based on the simplex PCR results, we developed a novel multiplex PCR method for the four LM cotton varieties (Fig. 3). To increase the amplification intensity of small PCR fragments, we used 4 pmol of primers for COT102 and 2 pmol for the other three LM cotton events (viz., MON88701, T304-40, and DAS81910-7) in the multiplex PCR analysis; the amplification intensity was sufficient in the multiplex PCR. The PCR product size of the four LM cotton events was 108 (COT102), 205 (MON88701), 277 (T304-40), and

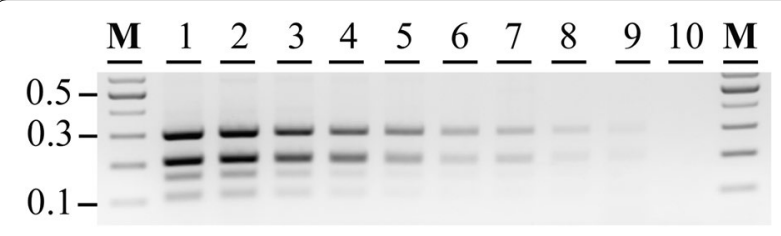

Fig. 4 Limit of detection (LOD) of multiplex PCR. Serially diluted four reference materials (RMs) with non-living material (LM) cotton genomic DNA was tested. Lanes 1-10: 50, 25, 12.5, 6.25, 3.12, 1.56, $0.78,0.39,0.19$, and $0 \mathrm{ng} / \mu \mathrm{L}$ (no template, control) genomic DNA, respectively. M represents 100 bp marker

371 bp (DAS-81910-7), as expected. These results indicated that the newly developed event-specific multiplex PCR could detect each event without any non-specific reaction.

\section{Limit of detection}

In many cases, the quality and quantity of genomic DNA from LMO monitoring samples might not be sufficient to identify event information. Therefore, the minimum concentration of genomic DNA that could be detected using the multiplex PCR is crucial [9]. The LOD was estimated using a dilution series of the four mixed RM DNA mixtures (Fig. 4). The results indicated that each event-specific PCR band was amplified at a genomic DNA concentration of $12.5 \mathrm{ng} / \mu \mathrm{L}$. Thus, our multiplex PCR method assured efficient detection at a low concentration of DNA and therefore could be applied to verify cotton varieties in LM monitoring. 


\section{Verification of the efficiency of multiplex PCR}

Randomly mixed RM DNA mixtures with non-LM DNA was used to confirm the sensitivity and efficiency of the multiplex PCR method for cotton. The results revealed that the multiplex PCR method can effectively detect all randomly mixed cotton RM DNA samples (Fig. 5). The multiplex PCR results with randomly mixed RM mixtures suggested that this method can identify all LMO stacks, including the four LM cotton varieties that will be approved in the future. The multiplex PCR method was applied to identify LM samples, which were collected from environmental monitoring [9-11]. To verify the application of multiplex PCR method in LMO monitoring, we used LM cotton samples collected from an LMO monitoring project in the Republic of Korea in 2018. Eighty-one cotton volunteer samples were further analyzed to identify and confirm the efficiency of the multiplex PCR method developed in this study (Fig. 6). Among the 81 LM cotton volunteers, 66 LM cotton varieties were further identified using the multiplex PCR method (Additional file 1: Table S1). These results indicated that the established multiplex PCR method can be used to detect and identify volunteers in LMO environmental monitoring.

\section{Discussion}

After more than 20 year of development of GMOs, there are more than $300 \mathrm{GM}$ crops in research or global development pipelines and more than 100 GMOs (10 crops) have entered the market or were released into the environment [1]. LMOs have been controversial owing to their adverse effects on the conservation and sustainable use of biological diversity, besides the risks to human health [12].

Several methods based on nucleic acid or proteins have been employed to detect and identify LMOs.

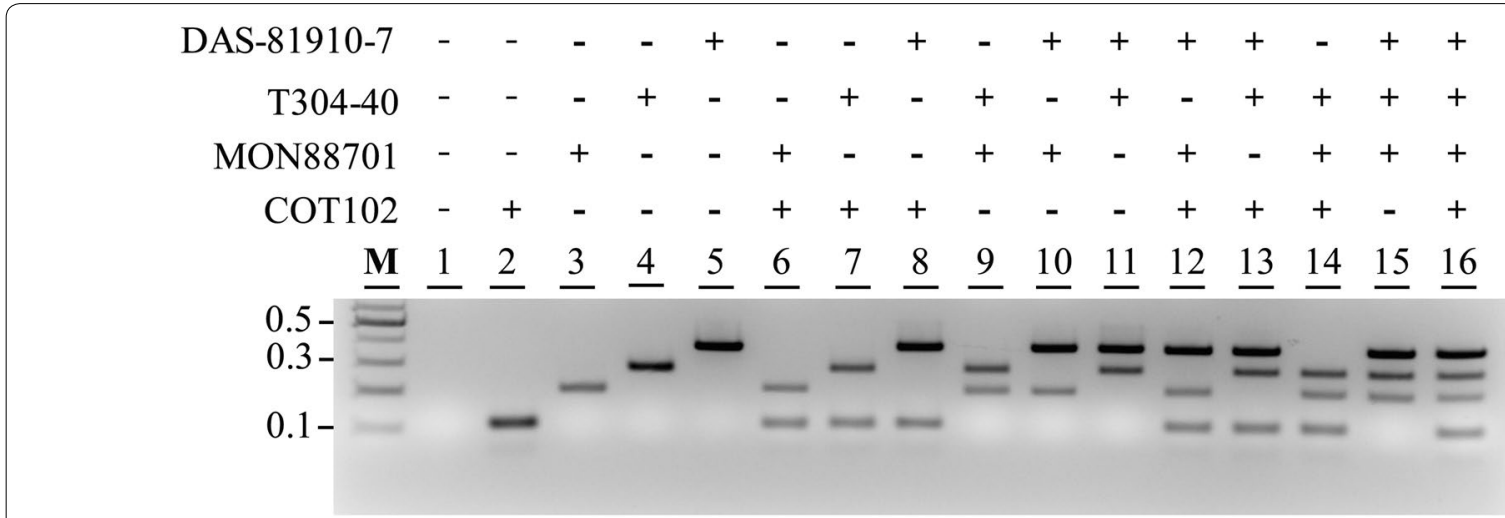

Fig. 5 Efficiency of multiplex PCR using a random living material organism (LMO) reference material (RM) mixture. Random mixtures of LM cotton genomic DNA were used as multiplex PCR templates. Total DNA amount was 50 ng in each reaction. Lane 1, non-LM; lanes 2-16, random mixtures of LM cotton RMs. M represents 100 bp marker

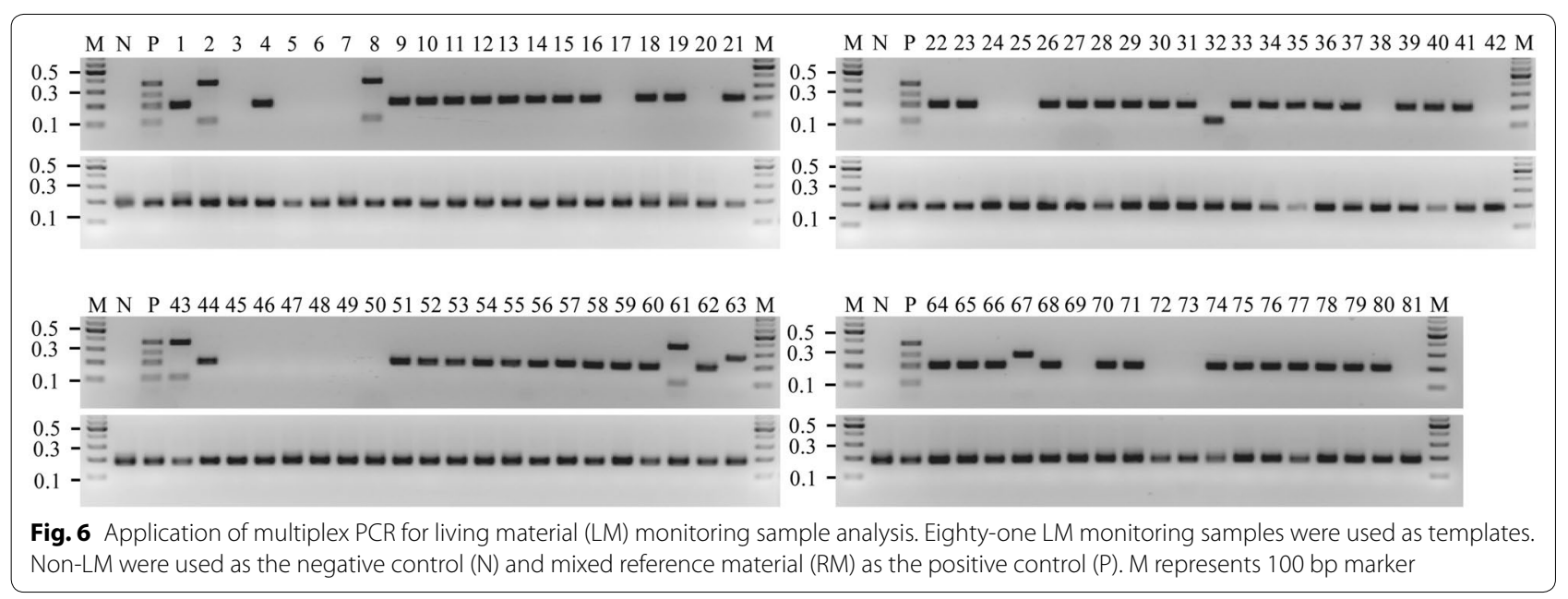


Developing reliable detection methods is crucial for the detection of LM materials in food and identification of unauthorized LMOs. Moreover, rapid and cost-effective detection methods, such as multiplex PCR, can be adopted to identify LMOs in transboundary movement or the environment $[13,14]$. In this study, we developed an event-specific multiplex PCR method to detect four LM cotton varieties and applied the novel method to identify unintentionally released LMOs into the environment. Compared with those of the conventional PCR detection method, new techniques such as realtime PCR are highly sensitive and convenient owing to their short reaction time; moreover, they do not require post-PCR manipulations [15]. However, developing a multiplex PCR method using real-time PCR system is difficult due to the interference between pairs of primers and limitation of probe combinations, reducing the sensitivity and efficiency [3]. Currently, some multiplex real-time PCR methods have been reported to simultaneously detect a few targets using universal target genes [16]. Several factors can affect the sensitivity and specificity of multiplex PCR. Among them, the ratio between primer and template is especially important [14]. In our previous study, we developed a multiplex PCR method for four GM soybeans and applied the same concentration of primers [9]. However, the concentration of some primers was too low for multiplex PCR, and the smallest target product could not be amplified exponentially [9]. In the present study, to improve the efficiency of multiplex PCR, we doubled the amount of COT102 primers, and the results showed that all multiplex PCR products were amplified effectively. This equal amplification can reduce false negative results in GMO detection. Furthermore, the simplex PCR results indicated that the efficiency of the newly developed simplex PCR was considerably higher than that reported for the JRC method.

Among the multiplex detection methods for major GM crops, those for cotton have not been well studied because cotton is not a food crop. Multiplex PCR methods have been developed for MON15985, MON531, GHB614, MON88913, LLCOTTON25, and MON1445-2 [10], GHB119 and 281/3006 [17], and GHB119 and T304-40 [3]. In this study, a conventional multiplex PCR method for COT102, MON88701, T304-40, and DAS-81910-7 was newly developed to identify approved GM cotton varieties in Korea. Currently, 14 GM cotton events have been approved for food, feed, and processing in Korea, and the multiplex PCR method included in this study has been developed by the National Institute of Ecology. MON757 and COT67B event-specific detection methods are under development, and simplex method can be applied for GM cotton identification.
The successful establishment and validation of GMO detection methods depend on the supplement of food and feed RMs and certified RMs [18]. The reference materials are required for qualitative and quantitative PCRs to screen and identify GMOs as the positive controls to monitor whether the established PCR method works properly and to quantify GM DNA in the total DNA [19]. Recently, issues related to unintentional transboundary movements and capacity building were discussed at the CBD held in 2018 to provide appropriate RMs that will enable laboratory work on the detection and identification of LMOs. In the future, the operator, the concept of which has not been well defined, might require providing information or access to RMs for regulatory purposes. The LOD of GMO detection methods has been evaluated based on the target DNA's copy number [20], and it depends on DNA quality, DNA extraction method, PCR primer specificity, and PCR premix type [21]. For high-sensitive detection, large amount of DNA as template is used; however, environmental sample of LMO cannot ensure DNA quality and quantity. Several testing methods released by developers or regulators and several previously reported GMO detection methods recommend that the minimum amount of purified DNA required is $40-100 \mathrm{ng}$ in total reaction volume $[6,10,11]$. In this study, we detected LMOs using the newly developed multiplex PCR method, which required only $12.5 \mathrm{ng}$ of purified DNA.

Since 2009, the Ministry of Environment and National Institute of Ecology in the Republic of Korea has been performing LMO environmental monitoring to implement the post-management strategies of LMO unintentional release into natural environment [22]. Whole cottonseed and cottonseed meals are sources of edible fat for dairy cattle [23]. Therefore, the total imported LM cotton seeds increased from 92 thousand tons in 2008 to 151 thousand tons in 2017 in Korea [24]. With the increasing use of whole cottonseed for feed in Korea, the number of unintentionally released LM cotton varieties has consistently increased [22]. Thus, there is a need to develop multiplex PCR methods to identify suspected LM samples during LMO monitoring.

\section{Supplementary information}

Supplementary information accompanies this paper at https://doi. org/10.1186/s13765-019-0459-8.

Additional file 1: Table S1. Information of event analysis obtained using the newly developed multiplex PCR.

Abbreviations

CBD: Convention on Biological Diversity; GMO: genetically modified organism; HR: herbicide tolerance; IR: insect resistance; LMO: living modified organism; 
LOD: limit of detection; PCR: polymerase chain reaction; RM: reference material.

\section{Acknowledgements}

Not applicable.

\section{Authors' contributions}

JRL and WC conceived and designed of the study. SJE, IRK, and HSL performed all experiments and collected plant samples. SJE and WC wrote the paper. All authors read and approved the final manuscript.

\section{Funding}

This study was supported by a grant from the National Institute of Ecology (NIE), funded by the Ministry of Environment (MOE) of the Republic of Korea (NIE-A-2019-06, NIE-A-2019-07).

\section{Availability of data and materials}

Not applicable.

\section{Competing interests}

The authors declare that they have no competing interests.

Received: 6 August 2019 Accepted: 16 September 2019

Published online: 05 October 2019

\section{References}

1. ISAAA (2017) Global Status of Commercialized Biotech/GM Crops in 2017. Biotech crop adoption surges as economic benefits accumulate in 22 years. ISAAA Brief No. 53. http://www.isaaa.org/resources/publicatio ns/briefs/53/default.asp. Accessed 01 Aug 2019

2. Yang L, Pan A, Zhang K, Yin C, Qian B, Chen J et al (2005) Qualitative and quantitative PCR methods for event specific detection of genetically modified cotton Mon1445 and Mon531. Transgenic Res 14:817-831

3. Li X, Wang X, Yang J, Liu Y, He Y, Pan L (2014) A novel quadruplex real-time PCR method for simultaneous detection of Cry2Ae and two genetically modified cotton events (GHB119 and T304-40). BMC Biotechnol 14:43

4. Singh M, Bhoge RK, Randhawa G (2016) Crop-specific GMO matrixmultiplex PCR: a cost-efficient screening strategy for genetically modified maize and cotton events approved globally. Food Control 70:271-280

5. Rosa SF, Gatto F, Angers-Loustau A, Petrillo M, Kreysa J, Querci M (2016) Development and applicability of a ready-to-use PCR system for GMO screening. Food Chem 201:110-119

6. Sawazaki HE, Duarte AP, Fuzatto MG, Sawazaki E, Grandi SHR, de Ponte JF et al (2015) Identification and quantification of corn, soybean and cotton genetically modified by real time PCR. Am J Mol Biol. 5:84-93

7. Liang C, van Dijk JP, Scholtens IM, Staats M, Prins TW, Voorhuijzen MM et al (2014) Detecting authorized and unauthorized genetically modified organisms containing vip3A by real-time PCR and next-generation sequencing. Anal Bioanal Chem 406:2603-2611

8. Holst-Jensen A, Rønning SB, Løvseth A, Berdal KG (2003) PCR technology for screening and quantification of genetically modified organisms (GMOs). Anal Bioanal Chem 375:985-993
9. Choi W, Seol MA, Jo BH, Kim IR, Lee JR (2018) Development and application of a novel multiplex PCR method for four living modified soybeans. Appl Biol Chem. 61:635-641

10. Jo BH, Seol MA, Shin SY, Kim IR, Choi W, Eum SJ et al (2016) Multiplex PCR method for environmental monitoring of approved LM cotton events in Korea. J Plant Biotechnol. 43:91-98

11. Shin SY, Lim HS, Seol MA, Jung YJ, Kim IR, Song HR et al (2016) Four multiplex PCR sets of $11 \mathrm{LM}$ maize for LMO environmental monitoring in Korea. J Plant Biotechnol. 43:473-478

12. Prakash D, Verma S, Bhatia R, Tiwary BN (2011) Risks and precautions of genetically modified organisms. ISRN Ecol. https://doi. org/10.5402/2011/369573

13. Morisset D, Demšar T, Gruden K, Vojvoda J, Štebih D, Žel J (2009) Detection of genetically modified organisms-closing the gaps. Nat Biotechnol. 27:700-701

14. Shrestha HK, Hwu KK, Chang MC (2010) Advances in detection of genetically engineered crops by multiplex polymerase chain reaction methods. Trends Food Sci Technol 21:442-454

15. Cottenet G, Blancpain C, Sonnard V, Chuah PF (2013) Development and validation of a multiplex real-time PCR method to simultaneously detect 47 targets for the identification of genetically modified organisms. Anal Bioanal Chem 405:6831-6844

16. Pansiot J, Chaouachi M, Cavellini L, Romaniuk M, Ayadi M, Berthear Y et al (2011) Development of two screening duplex PCR assays for genetically modified organism quantification using multiplex real-time PCR master mixes. Eur Food Res Technol 232:327-334

17. National Institute of Ecology (2015) Development of multiplex-PCR for simultaneous detection of LMOs. NIE, Seocheon (in Korean)

18. Wu Y, Li J, Li X, Zhai S, Gao H, LiY et al (2019) Development and strategy of reference materials for the DNA-based detection of genetically modified organisms. Anal Bioanal Chem 411:1729-1744

19. Lauwaars M, Anklam E (2004) Method validation and reference materials. Accred Qual Assur 9:253-258

20. Mano J, Hatano S, Nagatomi Y, Futo S, Takabatake R, Kitta K (2018) Highly sensitive GMO detection using real-time PCR with a large amount of DNA template: single laboratory validation. J AOAC Int 101:507-514

21. Gryson N (2010) Effect of food processing on plant DNA degradation and PCR-based GMO analysis: a review. Anal Bioanal Chem 396:2003-2022

22. National Institute of Ecology (2018) Study on environmental monitoring and post-management of LMO. NIE, Seocheon (in Korean)

23. Arieli A (1998) Whole cottonseed in dairy cattle feeding: a review. Anim Feed Sci Technol 72:97-110

24. KBCH: Korea Biosafety Clearing House (2018) Status of risk assessment of GMO in Korea. http://www.biosafety.or.kr. Accessed 01 Aug 2019

\section{Publisher's Note}

Springer Nature remains neutral with regard to jurisdictional claims in published maps and institutional affiliations.

\section{Submit your manuscript to a SpringerOpen ${ }^{\oplus}$ journal and benefit from:}

- Convenient online submission

- Rigorous peer review

- Open access: articles freely available online

- High visibility within the field

Retaining the copyright to your article

Submit your next manuscript at springeropen.com 